\title{
Study of Humanitarian High School Students' Readiness for Intercultural Communication Formation
}

\author{
Minnisa S. Safina ${ }^{1} \&$ Agzam A. Valeev ${ }^{1}$ \\ ${ }^{1}$ Kazan (Volga region) Federal University, Kazan, Russia \\ Correspondence: Agzam A. Valeev, Kazan Federal University, Kremlyovskaya Street 18, Kazan, 420008, Russia. \\ E-mail: valeykin@yandex.ru
}

Received: January 19, 2014

Accepted: February 22, 2015 Online Published: March 25, 2015

doi:10.5539/res.v7n5p52

URL: http://dx.doi.org/10.5539/res.v7n5p52

\begin{abstract}
The scope of the international activity of Russia has increased today. This fact demands a good knowledge of foreign languages. Foreign languages are used by high schools graduates in foreign offices of Russian companies, in foreign companies abroad and for communication in all sorts of professional conferences. Modern high school graduates' competitive advantage, career and success in life is determined along with qualifying characteristics by their following abilities: to adapt to the new information space in the international environment; to be professionally trained to participate in international business communications; to be able to adapt all personal qualities in a particular labor market. Adequate verbal behavior in any profession requires the development of not only the language skills, but also knowledge of the laws, customs, and national mentality of the studied country language. All this requires a qualitatively new approach to foreign language teaching. The article reveals the essence and the basic characteristics of readiness for intercultural communication, the principles of readiness for intercultural communication formation and educational potential of the discipline "Foreign Language" in the formation of this readiness. The study found levels of the students' readiness for intercultural communication development , defined criteria and proposed diagnostic tools, and complex problem-communicative methods of social and functional competencies formation, providing professional orientation and substantial basis in the course of students' foreign language activities. The results of experimental work suggest the viability and validity of pedagogical conditions of humanitarian high school students' readiness for intercultural communication formation.
\end{abstract}

Keywords: intercultural communication, dialogue of cultures, linguistic environment, social competence, functional competence, socio-cultural competence, communication methods, professional orientation training, communication needs, students, humanitarian high school

\section{Introduction}

\subsection{Actualizing the Problem}

Increased interest in the problems of foreign language communication in modern world due to globalization is expressed not only in the process of business integration and expansion of information space, the development of new information technologies, expansion of business and personal contacts (Grigoryeva et al., 2015; Lopatina et al., 2015; Gutman et al., 2014; Masalimova et al., 2014). Modern era is marked by gradual entry of Russia into the international community, necessitating changes in conceptual approaches in teaching foreign language students who use a foreign language as a tool for future careers. The aim of teaching foreign languages, in this connection, is not mastery of a set of specific skills, but the formation of linguistic personality. For this kind of person a foreign language is necessary for life, for communication in real life situations and for being able to carry out effective communication with other cultures (Kamalova \& Zakirova, 2014). Contemporary societies require not just professionals but also specialists in international and intercultural communication. Formation of skills of intercultural communication as a methodological basis of language learning in high school seems justified especially for humanitarian students-lawyers, managers and others (Shaidullina et al., 2014, 2015; Valeeva et al., 2015; Biktagirova \& Valeeva, 2014; Lopatina et al., 2015). Hence, we observe more than ever urgent problem of formation of humanitarian high school students' readiness for intercultural communication. A tendency to establish links between the different regions of the globe on the basis of the international division of labor inevitably leads to the development of international communication, cultural and 
information exchange, strengthening interaction and mutual influence of peoples, nations, and civilizations in various spheres of social life including education (Ganieva et al., 2014, 2015)

\subsection{Explore Importance of the Problem}

Pedagogical understanding of the problem of foreign language communicative activities of students is related to the formation of ability to participate in intercultural communication. This problem is most relevant today, when a mixture of peoples, languages, cultures reached unprecedented proportions. In this regard, there is a question about the education of tolerance for other cultures, creating interest and respect for them (Valeeva \& Panteleeva, 2014).

In modern methods of teaching foreign languages the possession and the process of mastering foreign language communicative activities is qualified as intercultural communication. High school education is now called upon to contribute to the training of specialists who are aware of the increasing global interdependence between peoples and nations understanding the need for international solidarity and cooperation and ready to participate constructively in the dialogue of cultures, peoples, countries, regions and continents.

For modern specialists' training in the context of interethnic integration it is necessary to transit from formal knowledge to competency paradigm of education, and then to provide opportunities for the full formation of readiness for intercultural communication students (Khairullina et al., 2015). The study defined understanding of the phenomenology of intercultural communication as a set of specific processes of interaction between people belonging to different cultures and languages. When forming readiness for intercultural communication in learning a foreign language it is important to give students a clear understanding that knowledge of other cultures, which are coming or already have contacts are very useful. They must also have the ability to correctly interpret the data about other cultures. And this requires a broader context than the one that takes into account the representatives of the traditional approach. This implies the need for multidisciplinary research and the need to include a wide variety of disciplines. Thus, in addition to learning a foreign language (terminology, speech etiquette) it's necessary to study of the cultural environment, issues of geography, the peculiarities of culture and rules of conduct.

\subsection{The Problem of Students' Readiness to Intercultural Communication Formation}

Implementation of the general educational aspects of foreign language teaching in higher education in the context of students' readiness to intercultural communication formation involves the search for answering the following questions:

- How can and must the process of learning a foreign language participate in solving common educational problems in general? We are talking about those personal qualities that contribute to second language acquisition and its practical use as a means of familiarizing with the other national culture and means of communication with its bearers;

- What kind of qualities of the personality of the student should be formed, so that he is able to participate in intercultural communication in a foreign language? It's about finding solutions in two directions: to define a set of personality traits that enable it to carry out communication and clarification of personal qualities that make him able to communicate in the target language on intercultural level. Hence, the task of learning a foreign language includes development of the following personal qualities necessary for the successful implementation of communication in intercultural communication situations: the ability to see a community of people belonging to different societies; the ability to understand and accept differences and commonality in different models of reality, in the attitude, in the specific behavior (including speech) of representatives of other cultures; willingness to use a foreign language as a means of communication at every meeting with its carriers and the need for self-study it.

\subsection{Status of a Problem}

Various aspects of intercultural communication are studied quite extensively in Russian psycho-pedagogical researches. Multicultural education is considered by Kulagina (1999). The role of national culture in the educational process in the education system is studied by Kharisov (1998). Leontyeva, Petrenko and Petrova (2002) studied the problems of formation of tolerant attitudes. Principles and methods of tolerant person formation in the national regional conditions are studied by Pertseva (2002), Stepanov (2001). Development of intercultural communication is considered by Almazova (2003), Baryshnikov (2002). In linguistics, intercultural communication is studied in terms of identifying units that reflect the cultural identity of language, the problems verbal and nonverbal communication in the dialogue of cultures, language interference (Furmanova, 1993; Klyukanov, 1998). The problem of psychological development of individuals belonging to different cultures is 
represented by Persikova (2002). Questions of general intellectual and foreign language competence of students are examined in the studies of Bezyuleva (2002), Berdichesky and Solovieva (1993). The problems of preparing students to communicate with native speakers are discussed by Bernstein (2001), Sysoev (2001). Formation of University students' readiness for intercultural communication is examined by Date (1996), Fedenko (1996), Yankina (1999). Pedagogical bases of teaching intercultural communication in the integrated humanitarian course are studied by Nikolaeva (1999). The development of intercultural competence of lawyers is researched by Podstrahova (2000). Important provisions of the relationship of language and thought are discovered in the works of Vygotsky (2001), Salmina (2001). The theory of speech and language personality is represented in the works of Leontief (1997), Karaulov (1987). Consideration of the formation of speech activity of students from the perspective of developing a culture of verbal communication, willingness of students to self-improvement and self-development are presented in the works of Kagan (1988), Kohn (1969), Passov (1985). Questions of multicultural education personification are studied by Gabdulkhakov (2014).

\subsection{Hypothesis}

Analysis of theoretical studies and practical activities in the aspect of the developed problems showed that the formation of humanitarian high school students' readiness for intercultural communication foreign language classes will proceed successfully if the following conditions are met:

- Formation of the valuable attitude to foreign language learning as means of intercultural communication;

- Update students' linguistic and cultural knowledge;

- Immersion of the language atmosphere in learning by comparing languages and cultures;

- Integration of knowledge on special subjects and a foreign language;

- The use of active learning technologies, transforming the student in the subject of educational activities and giving him the opportunity to realize his need for communication.

\section{Materials and Methods}

\subsection{The Tasks of the Research}

The study addressed the following tasks: 1) to reveal the essence and the basic characteristics of readiness for intercultural communication on the basis of scientific analysis of philosophical, psychological, pedagogical, linguistic and didactical literature; 2) to define the principles of organization of this activity in a humanitarian high school; 3) to develop a set of methods and techniques of humanitarian high school students' readiness for intercultural communication formation; 4) to develop and test in experimental work efficiency of pedagogical conditions of readiness for intercultural communication formation.

\subsection{Theoretical and Empirical Methods}

To test the hypothesis there has been used a complex variety of methods, complementing each other:

- Theoretical—analysis of the literature; study and generalization of innovative teaching experience, analysis, synthesis;

- Empirical-participant observation, ascertaining and forming pedagogical experiment, survey, testing, interviews, discussions, study results of academic and extracurricular activities of students.

\subsection{The Trial Infrastructure and Stages of the Research}

Experimental base for the study was the Institute for Social and Human Knowledge and Kazan socio-humanitarian College. The study was conducted in three stages. On the purpose and content the carried out experiment was forming; under the terms it was mixed (traditional, cross, constant). Totally in 2010-2014 years in the experimental work there were involved 120 students of 1-2 courses of the Faculty of Law and the Faculty of Management of the Institute for Social and Human Knowledge and Kazan socio-humanitarian College. The experimental work was carried out under natural conditions of the educational process. The experiment consisted of three parts: ascertaining, forming and control.

In the first stage - ascertaining (2010-2011) - there surveyed practical English lessons to analyze the intercultural competence of students in the learning process.

The second stage - forming (2012-2013) — was devoted to experimental testing of complex pedagogical conditions in the formation of humanitarian high school students' readiness to intercultural communication. In the experimental groups special pedagogical conditions and applied teaching methods were created that helped to shape the students' readiness for intercultural communication. 
At the control (2013-2014) stage we evaluated the effectiveness of pedagogical conditions influencing the formation of the future specialists in the humanities readiness to intercultural communication.

\subsection{Evaluation Criteria}

During the experiment there were determined criteria and indicators of students' readiness to intercultural communication. On this basis the evaluation, definition, classification and performance of qualitative and quantitative characteristics of each personality traits were formed. We have chosen the following criteria for defining levels of students' readiness to intercultural communication:

- Social competence (willingness and desire to interact with others, self-confidence, the ability to put oneself in the others place and the ability to cope with the situation in the society);

- Functional competence (the ability to express one's own opinion, agreement, disagreement, interest, sympathy, surprise, other emotions, intention and ability to influence the interlocutor);

- Socio-cultural competence (the ability to navigate in space and time, in the social status of the speaker, in the use of language norms (formal / informal style, taboo slang, professional vocabulary, etc.), willingness and ability to conduct a dialogue of cultures, which implies a knowledge of own culture and the culture of the studied language country).

\subsection{Experimental Procedure and Its Description}

In the process of ascertaining stage of the experiment there was carried out diagnostics of readiness for intercultural communication through a set of methods: questionnaires, observations, interviews with students and teachers, the study of products of students' learning activities (examinations), the analysis of students' achievements. There have been identified the level of students' social, functional and socio-cultural competence development. At the stage of ascertaining experiment there have also been monitored the students' communication abilities during tests and examinations in English.

The experiment was performed in the control and experimental groups. It was found that the state of readiness for intercultural communication at the beginning of the experimental work was at the same low level: the average score was 3.7 in the experimental and control groups.

We divided the levels of students' readiness to intercultural communication into high, medium and low:

- High level of readiness for cross-cultural communication is characterized by the formation of all three components;

- The average level is characterized by incomplete formation of a coherent structure of readiness for intercultural communication, the uneven development of its separate components;

- Low level of readiness for intercultural communication involves a condition in which some of its components operate weakly, because it is not activated by the internal needs of the individual, but only by external requirements.

Analysis of the state of future specialists in the humanities readiness formation was held before the experiment, after completing it, as well as during the semesters. Thus, the results of ascertaining experiment showed that the majority of students were experiencing difficulties in organization and implementation of intercultural communication.

The problem of readiness for intercultural communication formation using the educational potential of discipline "Foreign Language" took into account the specifics and scope of cultural information that should be assimilated; interdisciplinary nature of a foreign language in the general system of the humanities; professional orientation of teaching a foreign language in high school; features of intercultural communication in an interlingua educational space; the specifics of the English language as a means of international communication. In this regard, the following tasks were solved in the course of the experiment: 1) to identify the levels and components of readiness for intercultural communication; 2) to study the dynamics of the state of the future specialists in the humanities readiness to intercultural communication; 3) to determine the relationship between the experimental system of preparedness for cross-cultural communication and efficiency of foreign language teaching and speech activity of students and the development of their speech knowledge and skills, as well as the degree of autonomy and cognitive activity of students, their satisfaction with their own speech activity; 4) to help students determine the importance of the dialogue of cultures especially for experts in the of sphere of speech responsibility specialists in the humanities: lawyers, managers, etc.; 5) to form the social competence of students; 6) to promote students to improve their social and functional competencies; 8) to facilitate the students in improving their level of motivation of learning a foreign language. 


\section{Results}

3.1 Methods of Formation of Readiness for Intercultural Communication in the Process of Learning a Foreign Language

Learning a foreign language was performed in three aspects: pragmatic (or practical), cognitive and educational.

The pragmatic aspect of learning a foreign language was aimed at the formation of a set of knowledge and skills to implement successfully the foreign-language speech communication.

Cognitive aspect goals of foreign language teaching was aimed at developing students' speech and language abilities; on the formation of their abilities and skills in the use of rational methods of mastering a foreign language; the organization of foreign language communicative activities; the use of language as a means of intercultural communication.

General Education aspect of a foreign language as a high school subject was aimed at developing the students' ability to understand the goals and motives of the representatives of different cultures and respond to their specific manifestations of verbal and nonverbal behavior due to cultural traditions and different value orientations accepted by a society.

The course of the experiment led to the following conclusions about the levels of foreign language knowledge.

- Requirements to the end of the 1 st level of foreign language knowledge: students show the presence of linguistic and communicative competence sufficient for further training activities, as well as for business contacts at the elementary level. Students have the following foreign language communication skills: in reading-introductory reading at a rate of 150 words / minute, without a dictionary; in speaking and listening - the ability to carry out the dialogue in relation to the content of the text, possession of speech etiquette of everyday communication, understanding monologue utterance within these areas and situations of communication; in writing-written communication implementation intentions;

- Requirements to the end of the 2nd level of foreign language knowledge: students show the presence of communicative competence required for foreign language activities in various fields, as well as for the business professional communication; ability to work with the original cross-cultural, non-fiction, special literature, reviews, scientific articles; in speaking and listening - to carry out a productive dialogue and express certain communicative intentions; in writing - the ability to establish business contacts, to make the presentations / reports, questionnaires, translated from foreign languages into Russian and from Russian into a foreign language;

- Requirements to the end of the 3rd level of foreign language knowledge: students show the presence of the communicative competence required for skilled information and creative activities in different areas and situations of business partnerships, joint production and research.

\subsection{The Procedure and Results of the Experiment}

To carry out the experimental work we have formed four groups of students (30 people each) 1-2 courses of the Faculty of Law and the Faculty of Management of the Institute for Social and Human Knowledge and Kazan socio-humanitarian College.

Continuously during the experiment we analyzed and synthesized the results of the developed complex of pedagogical conditions efficiency for the formation of readiness for intercultural communication. The results were reflected then in the completed by students themselves "maps for readiness", as well as in the process of questioning and analyzing the results. For the main component of readiness was taken social competence of the person that contributed to the formation of functional competence and socio-cultural competence. To identify the level of formation of social competence of the person we used a variety of methods: observation, conversations, interviews, self-examination, self-esteem, the survey. Using these techniques we received sufficient information about the social competence of students. The experimental results are shown in Table number 1. 
Table 1. Dynamics of students' social competence by semester

\begin{tabular}{|c|c|c|c|c|c|c|}
\hline \multirow[t]{2}{*}{ Semester } & \multicolumn{3}{|c|}{ Assessment of experimental groups } & \multicolumn{3}{|c|}{ Assessment of control groups } \\
\hline & High & Medium & Low & High & Medium & Low \\
\hline \multirow[t]{2}{*}{1} & 15 & 24 & 21 & 13 & 29 & 18 \\
\hline & Average 3.9 & & & Avera & & \\
\hline \multirow[t]{2}{*}{2} & 17 & 28 & 15 & 13 & 31 & 16 \\
\hline & Average 4.0 & & & Avera & & \\
\hline \multirow[t]{2}{*}{3} & 20 & 30 & 10 & 13 & 32 & 15 \\
\hline & Average 4.1 & & & Avera & & \\
\hline \multirow[t]{2}{*}{4} & 25 & 32 & 3 & 13 & 33 & 14 \\
\hline & Average 4.3 & & & Avera & & \\
\hline
\end{tabular}

Analysis of the state of students' readiness of control and experimental groups at the end of the experiment shows that the average overall score of readiness in the experimental groups increased from 3.7 to 4.3 points, and the control groups-from 3.7 to 3.8 points.

Comparison of mean scores of a state of readiness in the control and experimental groups in $\mathrm{t}$ T-test showed a significant difference in them as a whole and for each component.

The difference in mean score on the social and socio-cultural components are significant at $\mathrm{p}<0.01$; on functional competence- significant at $\mathrm{p}<0,05$.

General state of readiness of the control and experimental groups are significantly at $p<0.01$. The experimental results are shown in Table 2.

Table 2. Readiness status of intercultural communication students control and experimental groups at the end of the experiment

\begin{tabular}{|c|c|c|c|c|c|c|}
\hline \multirow[t]{2}{*}{ Group } & \multirow[t]{2}{*}{ Components } & \multicolumn{3}{|c|}{ Level components of readiness (\%) } & \multirow{2}{*}{$\begin{array}{l}\text { The } \\
\text { average } \\
\text { score }\end{array}$} & \multirow{2}{*}{$\begin{array}{l}\text { The total } \\
\text { score }\end{array}$} \\
\hline & & High & Medium & Low & & \\
\hline $\begin{array}{l}\text { The } \\
\text { experimental }\end{array}$ & Social competence & 41.9 & 52.3 & 5.8 & 4.4 & \\
\hline \multirow[t]{2}{*}{ group } & functional competence & 30 & 63.35 & 6.65 & 4.2 & 4.3 \\
\hline & $\begin{array}{l}\text { sociocultural } \\
\text { competence }\end{array}$ & 38.35 & 56.65 & 5,0 & 4.4 & \\
\hline \multirow{3}{*}{$\begin{array}{l}\text { The } \\
\text { group }\end{array}$} & Social competence & 22 & 55 & 23 & 3.9 & \\
\hline & functional competence & 18.3 & 48.3 & 33.4 & 3.8 & 3.8 \\
\hline & $\begin{array}{l}\text { sociocultural } \\
\text { competence }\end{array}$ & 25 & 46.6 & 28.4 & 3.9 & \\
\hline
\end{tabular}

During the experiment, we observed increasing activity of students, their interest in the language, to extracurricular pursuits, the desire for self-development. All this allows to speak about the effectiveness of developed pedagogical conditions implementation.

\section{Discussions}

The basic premise which contributed to the formation of high school students' readiness to intercultural communication is the increasing role of foreign languages and its influence on the spiritual and intellectual 
development of young people. Hence the willingness to intercultural communication is an integrative personal growth suggesting at least some level of a foreign language knowledge, linguistic and cultural orientations and communicative skills. Formation of readiness for intercultural communication needs to be studied in conjunction with the social setting. The main phenomena of socialization are the assimilation of behavioral, social norms, customs, interests and values. The unity and the high level of the components listed below are a sign of readiness: social competence, functional competence, socio-cultural competence.

Foreign language plays an important role in the process of students' readiness to intercultural communication formation there. A foreign language has pragmatic, cognitive and general learning objectives. An important task of learning a foreign language is the development of personal qualities necessary for the successful implementation of communication in intercultural communication situations like the ability to see a community of people belonging to different societies; the ability to understand and accept differences and commonality in different models of reality, in the attitude, in the specific behavior (including speech) representatives of other cultures; to use a foreign language as a means of communication at every meeting with native speaker and the need for self-study.

\section{Conclusion}

The proposed article considers purposes, the content and organization of learning a foreign language in the formation of readiness of humanitarian high school students to intercultural communication at the forefront displays the following ways to improve this process:

- Drawing up appropriate solution of the problem of training programs;

- The introduction of additional material to the content of foreign language teaching;

- The application of modern principles in foreign language teaching;

- Applying special methods of active social learning of students in formation of intercultural communication in order to form their basic components of preparedness;

- The study of the theoretical aspects of the problem of humanitarian high school students' readiness to intercultural communication formation.

On the basis of the principles of formation of readiness for intercultural communication (the principle of cultural saturation content of the material; the principle of focusing on humanitarian values; the principle of tolerance; the principle of dialogue between cultures; the principle of activity; the principle of the formation of a secondary language personality traits) certain pedagogical conditions for effective implementation were identified and substantiated: the formation of value attitude to learning a foreign language as a means of intercultural communication; linguistic and cultural actualization of students' knowledge; immersion in the language atmosphere by comparing in learning languages and cultures; integration of knowledge on special subjects and a foreign language; the use of active learning technologies, transforming the student in the subject of learning activities and giving him the opportunity to realize his need for communication.

\section{Acknowledgments}

The work is performed according to the Russian Government Program of Competitive Growth of Kazan Federal University

\section{References}

Almazova, N. I. (2003). Cross-cultural component of foreign language communication: Cognitive and didactic aspects. St. Petersburg: Nauka.

Baryshnikov, N. V. (2002). Training parameters of intercultural communication in high school. Foreign languages at school, 2, 28-32.

Berdichevsky, A. L., \& Soloviev, N. (1993). Dialogue of cultures in the classroom with native and foreign languages. Foreign languages at school, 6, 5-11.

Bernstein, V. L. (2001). Preparing students for communication with native speakers ( $\mathrm{PhD}$ dissertation). Pyatigorsk.

Bezyuleva, G. V., \& Shelamova, G. M. (2002). Tolerance in pedagogy. Moscow: Akad. prof. education.

Biktagirova, G. F., \& Valeeva, R. A. (2014). Development of the teachers' pedagogical reflection. Life Science Journal, 11(9), 60.

Fedenko, L. N. (1996). Intercultural communication as a condition of a common educational space. Orenburg. 
Furmanova, V. G. (1993). Intercultural Communication and linguistic-cultural studies in the theory and practice of teaching foreign languages. Saransk: Mord.univ. Publ.

Gabdulkhakov, V. F. (2014). Personification of Multicultural Education in the Universities of Russia (Analysis of Training Specialists for Kindergartens). Procedia-Social and Behavioral Sciences. Third Annual International Conference "Early Childhood Care and Education", 146, 129-133. http://dx.doi.org/10.1016/j.sbspro.2014.08.099

Ganieva, Y. N., Azitova, G. S., Chernova, Y. A., Yakovleva, I. G., Shaidullina, A. R., \& Sadovaya, V. V. (2014). Model of High School Students Professional Education. Life Science Journal, 11(8s), 1097-8135.

Ganieva, Y. N., Sayfutdinova, G. B., Yunusova, A. B., Sadovaya, V. V., Schepkina, N. K., Scheka, N. Y., Gutman, E. V., \& Salakhova, V. B. (2015). Structure and content of higher professional school lecturer education competence. Review of European Studies, 7(4), 32. http://dx.doi.org/10.5539/res.v7n4p32

Grigoryeva, E. V., Leyfa, I. I., Yatsevich, L. P., Pavlushkina, T. V., \& Masalimova, A. R. (2015). Designing technology of English language teaching content based on international component. Review of European Studies, 7(1), 123-129.

Gutman, Y. Y., Masalimova, A. R., Shaidullina, A. R., Nizamieva, A. M., \& Mukhamadieva, A. H. (2014). Foreign language discipline integrative potential in the students' research competence development. American Journal of Applied Sciences, 11, 1099-1103. http://dx.doi.org/10.3844/ajassp.2014.1099.1103

Harisov, F. F. (1998). Language and nation: Environmental problems in terms of multilingualism. Kazan: RIP "School".

Ivanenko, N. A., Akhmetov, L. G., Lavrentiev, S. Y., Kartashova, E. P., Lezhnina, L. V., Tzaregorodtzeva, K. A., \& Khairullina, E. R. (2015). Features of Modeling the Formation of Teaching Staff Competitiveness. Review of European Studies, 7(3), 37-42. http://dx.doi.org/10.5539/res.v7n3p37

Kagan, M. S. (1988). World of communication: Problems intersubjective relations. Moscow: Politizdat.

Kamalova, L. A., \& Zakirova, V. G. (2014). Technique of comparative studying of the Russian and Tatar national fairy tales at modern elementary school in a context of dialogue of cultures. Middle East Journal of Scientific Research, 21(1), 33-37.

Karaulov, Y. N. (1987). Russian language and linguistic identity. Moscow: Nauka.

Khairullina, E. R., Valeyev, A. S., Valeyeva, G. K., Valeyeva, N. S., Leifa, A. V., Burdukovskaya, E. A., \& Shaidullina, A. R. (2015). Features of the Programs Applied Bachelor Degree in Secondary and Higher Vocational Education. Asian Social Science, 11(3), 213-217.

Klyukanov, I. E. (1998). The dynamics of intercultural communication: System-semiotic study. Tver: Publishing House of Tver University.

Kohn, I. S. (1966). Psychology of Prejudice (on social and psychological roots of ethnic prejudice). New world, 9, 187-205.

Kovaleva, N. I., Valeyeva, N. Sh., Avilova, N. L., Kharisova, G. M., Khayrutdinov, R. R., Khairullina, E. R., \& Shaikhlislamov, A. K. (2015). Recommended Practices for Improving the Competitiveness of the Russian Education Services Market under the Conditions of the International Educational Integration. Review of European Studies, 7(4), 1-5. http://dx.doi.org/10.5539/res.v7n4p1

Kulagina, S. G. (1999). Multicultural education and intercultural competence of the individual. Bulletin of the Orenburg State University, 3, 38-41.

Leontiev, A. A. (1997). Fundamentals of psycholinguistics. Moscow: Smysl.

Leontiev, E. O., Petrenko, V. V. \& Petrov, G. I. (2002). Tolerance and communication. Tomsk: Tomsk state Univ.

Lopatina, O. V., Borisov, A. M., Leyfa, I. I., Galimzyanova, I. I., Yatsevich, L. P., Demyanenko, M. A., \& Masalimova, A. R. (2015). Role of foreign language teacher shaping students' research skills. Asian Social Science, $11(4), 135$.

Lopatina, O. V., Fassakhova, G. R., Akhmetova, L. A., Gatin, R. G., Yarullina, A. S., Nikishina, S. R., \& Khairullina, E. R. (2015). The Technology of Forming the Students' Research Competence in the Process of Learning a Foreign Language. Asian Social Science, 11(3), 152-157.

Masalimova, A. R., Ikramova, G. D., Shaidullina, A. R., Gubaidullina, G. T., \& Apraksina, N. D. (2014). Distant in-company foreign language learning involving university student-tutors. American Journal of Applied 
Sciences, 11, 1123-1127. http://dx.doi.org/10.3844/ajassp.2014.1123.1127

Merzon, E. R., Fayzullina, A. R., Ibatullin, R. R., Krylov, D. A., Schepkina, N. K., Pavlushkina, T. V., \& Khairullina, E. R. (2015). Organizational and Pedagogical Conditions of Academic Mobility Development of Students at School of Higher Professional Education. Review of European Studies, 7(1), 46-51.

Nikolaeva, L. (1999). Pedagogical bases of teaching intercultural communication in the integrated course of the humanities ( $\mathrm{PhD}$ dissertation). Yakutsk: Yakutsk state university.

Passow, H. (1985). Communicative methods of teaching foreign language speech. Moscow: Education.

Persikova, T. N. (2002). Intercultural communication and corporate culture. Moscow: Logos.

Pertsev, A. V. (2002). Life strategy of tolerance: problems of formation in Russia and in the West. Ekaterinburg: Publishing House of Ur. Univ.

Podstrahova, A. V. (2000). Formation of the basic skills of intercultural communication: The experience of foreign language teaching in law school. Vladimir Pedagogical University Bulletin, 5, 242-251.

Sakhieva, R. G., Ibatullin, R. R., Biktemirova, M. K., Valeyeva, G. K., Pchelina, O. V., Valeyeva, N. Sh., Minsabirova, V. N., \& Khairullina, E. R. (2015). The Essential, Objective and Functional Characteristics of the Students' Academic Mobility in Higher Education. Review of European Studies, 7(3), 335-340. http://dx.doi.org/10.5539/res.v7n3p335

Salmin, J. I. M. (2001). Communication, Language, Thinking. Kazan: DAS.

Shaidullina, A. R., Masalimova, A. R., Vlasova, V. K., Lisitzina, T. V., Korzhanova, A. A., \&Tzekhanovich, O. M. (2014). Education, science and Manufacture Integration Models features in Continuous Professional Education System. Life Science Journal, 11(8s), 478-485.

Shaidullina, A. R., Merzon, E. E., Zakirova, V. G., Mokeyeva, E. V., Karev, B. A., Burdukovskaya, E. A., \& Polevaya, N. M. (2015). The Peculiarities of Perspective Students Selection Mechanism by the Future Employers-Enterprise. Review of European Studies, 7(1), 68-73.

Stepanov, P. (2001). Tolerant person: How to educate. Education, 6, 152-156.

Sysoev, P. V. (2001). Language and culture in search of a new direction in teaching the target language culture of the country: The content of socio-cultural component. Foreign languages at school, 4, 12-18.

The Date, M. (1996). Theoretical Foundations of intercultural communication training. In Russia and the West: Dialogue of Cultures (pp. 417-427). Moscow: MSU.

Valeeva, R. A., \& Panteleeva, M. V. (2014). Formation of intercultural competence in a poly-cultural interaction (based on American Studies). Fundamental studies, 5(4), 854-859.

Valeeva, R. A., Koroleva, N. E., \& Sakhapova, F. K. (2015). Civic education of the technical university students in foreign language classes. Review of European Studies, 7(1), 176-180.

Vygotsky, L. S. (2001). Thinking and speech, Psyche, consciousness, the unconscious. Moscow: Labyrinth.

Yankina, N. V. (1999). Formation of high school students' readiness to intercultural communication (PhD dissertation). Orenburg.

\section{Copyrights}

Copyright for this article is retained by the author(s), with first publication rights granted to the journal. This is an open-access article distributed under the terms and conditions of the Creative Commons Attribution license (http://creativecommons.org/licenses/by/3.0/). 